\title{
Insights on the Functions and Ecophysiological Relevance of the Diverse Carbonic Anhydrases in Microalgae
}

\author{
Erik L. Jensen ${ }^{1,+} \mathbb{D}$, Stephen C. Maberly ${ }^{2} \mathbb{D}$ and Brigitte Gontero ${ }^{1, * \mathbb{D}}$
}

1 Aix Marseille Univ, CNRS, BIP, UMR 7281, IMM, FR3479, 31 Chemin J. Aiguier, CEDEX 20, 13402 Marseille, France; erikjensenrojas@gmail.com

2 UK Centre for Ecology \& Hydrology, Lake Ecosystems Group, Lancaster Environment Centre, Library Avenue, Bailrigg, Lancaster LA1 4AP, UK; scm@ceh.ac.uk

* Correspondence: bmeunier@imm.cnrs.fr; Tel.: +33491164549

+ Current address: Institut de Biologie Physico-Chimique, Laboratory of Chloroplast Biology and Light Sensing in Microalgae, UMR7141 Centre National de la Recherche Scientifique (CNRS), Sorbonne Université, 75005 Paris, France.

Received: 16 March 2020; Accepted: 20 April 2020; Published: 22 April 2020

\begin{abstract}
Carbonic anhydrases (CAs) exist in all kingdoms of life. They are metalloenzymes, often containing zinc, that catalyze the interconversion of bicarbonate and carbon dioxide-a ubiquitous reaction involved in a variety of cellular processes. So far, eight classes of apparently evolutionary unrelated CAs that are present in a large diversity of living organisms have been described. In this review, we focus on the diversity of CAs and their roles in photosynthetic microalgae. We describe their essential role in carbon dioxide-concentrating mechanisms and photosynthesis, their regulation, as well as their less studied roles in non-photosynthetic processes. We also discuss the presence in some microalgae, especially diatoms, of cambialistic CAs (i.e., CAs that can replace $\mathrm{Zn}$ by Co, $\mathrm{Cd}$, or $\mathrm{Fe}$ ) and, more recently, a CA that uses $\mathrm{Mn}$ as a metal cofactor, with potential ecological relevance in aquatic environments where trace metal concentrations are low. There has been a recent explosion of knowledge about this well-known enzyme with exciting future opportunities to answer outstanding questions using a range of different approaches.
\end{abstract}

Keywords: carbonic anhydrase; microalgae; carbon dioxide; $\mathrm{CO}_{2}$-concentrating mechanisms

\section{Introduction}

Microalgae are a heterogenous group of eukaryotic and prokaryotic microorganisms that are almost exclusively photosynthetic, phylogenetically distinct, and evolved at different geological periods during the Earth's history [1]. The earliest prokaryotic photosynthetic microalgae, cyanobacteria, appeared more than 2.3 billion years ago [2]. Eukaryotic microalgae, including red and green lineages, evolved over 1.5 billion years ago as the result of an endosymbiosis event between a photosynthetic cyanobacterium and a heterotrophic eukaryote [3]. Other microalgae are the result of additional endosymbiotic events between photosynthetic microalgae and photosynthetic or non-photosynthetic hosts. Therefore, some microalgae are the result of a secondary (e.g., the stramenopiles), tertiary, or even quaternary (e.g., some dinoflagellates) endosymbiosis $[4,5]$. Microalgae are important primary producers in aquatic environments. Their success is in part the result of highly efficient photosynthetic $\mathrm{CO}_{2}$ fixation, which can be 10 to 50 times higher than that of land plants [6]. Moreover, this high efficiency can occur even in environments where $\mathrm{CO}_{2}$ is usually limiting, because microalgae have evolved different strategies to take up and fix $\mathrm{CO}_{2}$, all of which involve the enzyme carbonic anhydrase 
(CA; EC 4.2.1.1). Changing concentrations of $\mathrm{CO}_{2}$ and $\mathrm{O}_{2}$ on Earth have altered the availability of inorganic carbon for photosynthesis and influenced the evolution of microalgae [7].

CAs catalyze the reversible reaction of $\mathrm{CO}_{2}$ hydration to form $\mathrm{HCO}_{3}{ }^{-}$, which is otherwise slow, and they occur in all kingdoms of life. They have several functions including maintenance of the acid-base balance, lipid biosynthesis, and the uptake of inorganic carbon [8]. So far, eight different $C A s$ classes have been described $\left(\alpha-, \beta-, \gamma_{-}, \delta_{-}, \zeta_{-}, \eta_{-}, \theta-\right.$, including a recently described $\mathrm{I}-\mathrm{CA}$; Table 1) [9-14]. Although all classes of CA catalyze the same reaction, they seem to be unrelated, since they share little or no sequence or structural similarity. All CAs are metalloenzymes that commonly use $\mathrm{Zn}^{2+}$ as a metal ion cofactor; however, it is known that some classes are cambialistic and/or replace $\mathrm{Zn}^{2+}$ with other metals, such as $\mathrm{Cd}^{2+}, \mathrm{Co}^{2+}, \mathrm{Fe}^{2+}$, or $\mathrm{Mn}^{2+}$ [15]. Seven of the eight classes of $\mathrm{CA}$ (currently excluding $\eta$-CA found within Plasmodium sp [16]) occur within microalgae, potentially reflecting their evolutionary diversity but also their reliance on this enzyme for carbon fixation. In fact, some CAs classes were first discovered in microalgae (i.e., diatoms) [11,12,17]. Moreover, the class and subcellular distribution of CAs within microalgae cells can also vary among species, even in those belonging to the same family (Figure 1).
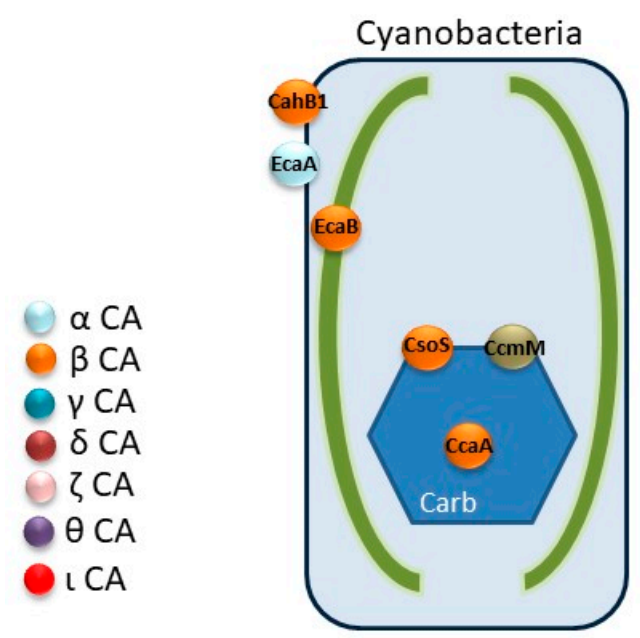

Diatoms (P. tricornutum)
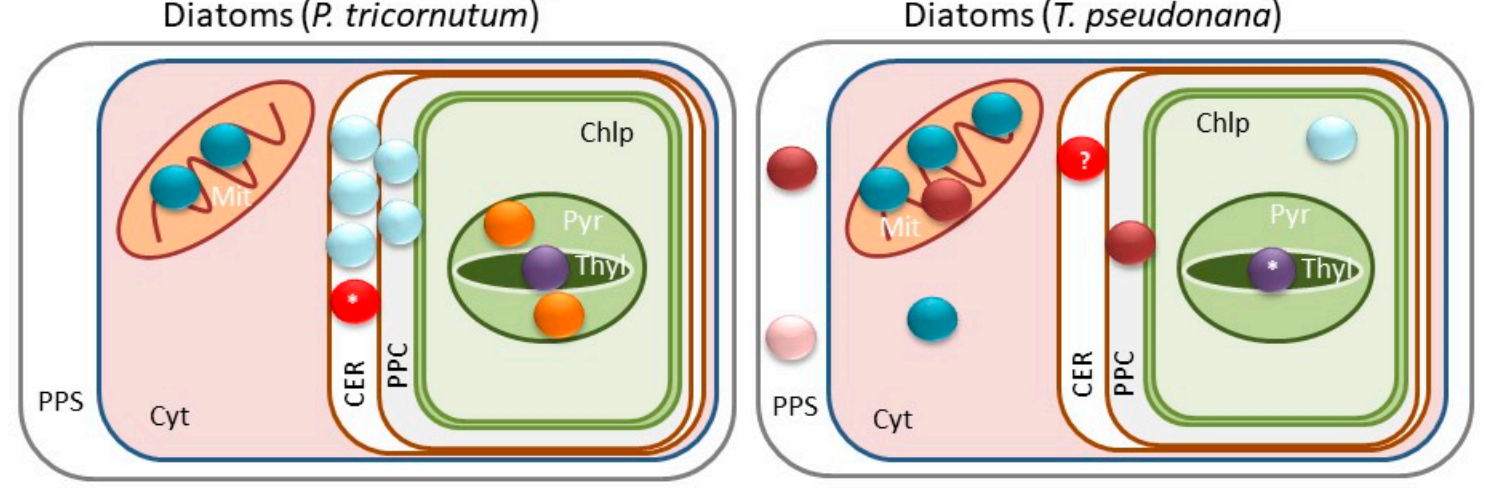

Figure 1. Distribution of the predicted carbonic anhydrases (CA) classes in some microalgae. Different CA classes are shown in colors as specified in the legend. In cyanobacteria and green algae, CAs appear also with their common names found in the literature. CAs whose subcellular localization is not fully demonstrated are shown with question marks (?); similarly, those that are predicted only by sequence homology appear with an asterisk $\left({ }^{*}\right)$. Carb: Carboxysome, Cyt: Cytoplasm, Mit: Mitochondrion, Chlp: Chloroplast (stroma), Thyl: Thylakoids (lumen), Pyr: Pyrenoid, PPS: Periplasmic space, CER: Chloroplast endoplasmic reticulum, PPC: Periplastidial compartment. 
Table 1. The different carbonic anhydrases (CA) classes, their metal cofactors, and distribution.

\begin{tabular}{cccc}
\hline CA Class & Metal Cofactor & Organism(s) & References \\
\hline$\alpha-\mathbf{C A}$ & $\mathrm{Zn}^{2+}$ & Mammals, plants, algae, prokaryotes & {$[18,19]$} \\
\hline$\beta-\mathbf{C A}$ & $\mathrm{Zn}^{2+}$ & Plants, algae, bacteria & {$[18]$} \\
\hline $\boldsymbol{\gamma}-\mathbf{C A}$ & $\mathrm{Zn}^{2+}, \mathrm{Fe}^{2+}, \mathrm{Co}^{2+}$ & Prokaryotes, plants, fungi, algae & {$[20]$} \\
\hline$\delta-\mathbf{C A}$ & $\mathrm{Zn}^{2+}, \mathrm{Co}^{2+}$ & Marine phytoplankton & {$[21,22]$} \\
\hline$\zeta-\mathbf{C A}$ & $\mathrm{Cd}^{2+}, \mathrm{Zn}^{2+}$ & Diatoms & {$[23]$} \\
\hline$\eta-C A$ & $\mathrm{Zn}^{2+}$ & Plasmodium sp & {$[16]$} \\
\hline $\boldsymbol{\theta}-\mathbf{C A}$ & $\mathrm{Zn}^{2+}$ & Diatoms, green algae & {$[11,24]$} \\
\hline t-CA & $\mathrm{Mn}^{2+}$ & Marine phytoplankton & {$[1,12]$} \\
\hline
\end{tabular}

In this review, we focus on the importance of CAs for inorganic carbon uptake in microalgae, on their role in the algal $\mathrm{CO}_{2}$-concentrating mechanisms, on their diversity, and how these enzymes help microalgae to survive and flourish in modern aquatic environments.

\section{The Need for $\mathrm{CO}_{2}$-Concentrating Mechanisms in Microalgae}

Aquatic environments are commonly limited by $\mathrm{CO}_{2}$ and so aquatic organisms cannot rely solely on passive $\mathrm{CO}_{2}$ uptake. For instance, in the oceans where the $\mathrm{pH}$ is between 7.8 and 8.4, only approximately $1 \%$ of the total dissolved inorganic carbon (DIC) is present in the form of $\mathrm{CO}_{2}$, bicarbonate being the most abundant inorganic carbon compound [25-27]. Moreover, at equilibrium with the atmosphere, the concentration of $\mathrm{CO}_{2}$ is around $15 \mu \mathrm{M}$, which is lower than the typical values of half saturation constant $\left({ }^{\mathrm{C}} \mathrm{K}_{0.5}\right.$ ) of the $\mathrm{CO}_{2}$-fixing enzyme ribulose 1,5-bisphosphate carboxylase oxygenase (Rubisco; ${ }^{C} K_{0.5}=100-180 \mu \mathrm{M}$ in cyanobacteria [28], 23-65 $\mu \mathrm{M}$ in diatoms [29], and 15-24 $\mu \mathrm{M}$ in haptophytes [30]). In addition, Rubisco-mediated carboxylation competes with the oxygenation of ribulose 1,5-bisphosphate (RuBP), which reduces carbon fixation and promotes photorespiration [31]. The extent to which these two competitive reactions occur depends on the $\mathrm{O}_{2}$ and $\mathrm{CO}_{2}$ concentrations at the active site of Rubisco and the relative affinity of the enzyme for the two gases. Thus, a $\mathrm{CO}_{2}$ uptake strategy based only on the diffusion of $\mathrm{CO}_{2}$ from the extracellular milieu to the chloroplast will restrict $\mathrm{CO}_{2}$ fixation rates at atmospheric $\mathrm{CO}_{2}$ concentrations. In fresh waters, $\mathrm{CO}_{2}$ concentrations substantially above and below air equilibrium can occur [32], providing an opportunity at high concentrations for species with relatively low abilities to exploit inorganic carbon [33] but producing more challenging inorganic carbon conditions when the concentration of $\mathrm{CO}_{2}$ is very low.

To cope with $\mathrm{CO}_{2}$ limitation, photosynthetic organisms evolved $\mathrm{CO}_{2}$-concentrating mechanisms (CCMs) to increase the concentration of $\mathrm{CO}_{2}$ in the vicinity of the Rubisco active site [34,35]. CCMs have been studied in several photosynthetic microalgae, including green algae [36-38], cyanobacteria [39], and diatoms [34,40]. A biochemical CCM involves the pre-fixation of $\mathrm{CO}_{2}$ into $\mathrm{C}_{4}$ organic compounds (i.e., oxaloacetate), which is a process termed $\mathrm{C} 4$ photosynthesis that occurs in $3 \%$ of terrestrial higher plants (e.g., Zea mays). This C4 metabolism is present in some aquatic plants (e.g., Hydrilla verticillata and Ottelia alismoides [41-43]) and in some green macroalgae (e.g., Ulva prolifera [44]). In contrast, although C4 photosynthesis has been proposed in the diatom Thalassiosira weissflogii (now called Conticribra weissflogii), more recent data indicate that this type of CCM is not widespread in microalgae [38,45-50].

Biophysical CCMs involving the active transport of inorganic carbon into the cell as $\mathrm{HCO}_{3}{ }^{-}$or $\mathrm{CO}_{2}$ are more frequent than biochemical CCMs in microalgae [51,52]. Cyanobacterial CCMs are based on the transport of $\mathrm{CO}_{2}$ or $\mathrm{HCO}_{3}{ }^{-}$and are extremely efficient, as they can elevate the $\mathrm{CO}_{2}$ concentration around Rubisco embedded within a polyhedral compartment called a carboxysome, 1000 times above the external $\mathrm{CO}_{2}$ concentration [39]. CCM components have been described both in marine and freshwater cyanobacteria and recently in cyanobacteria living in alkaline lakes [53]. Most bicarbonate transporters belong to the solute carrier family (SLC) and have been well described in mammals and 
humans [54]; however, other types of transporters have also been found in photosynthetic organisms. The first $\mathrm{HCO}_{3}{ }^{-}$transporter described in cyanobacteria was BCT1 from Synechococcus [55]. It belongs to the ATP-binding cassette (ABC) transporter family and has a $\mathrm{K}_{0.5}$ for $\mathrm{HCO}_{3}{ }^{-}$of $15 \mu \mathrm{M}$ [55]. It is encoded in the cmpABCD operon, which is highly induced by low $\mathrm{CO}_{2}$ [56]. However, all strong alkaliphilic cyanobacteria lack this transporter [53]. Other transporters described in cyanobacteria include the two $\mathrm{Na}^{+}$-dependent $\mathrm{HCO}_{3}{ }^{-}$plasma membrane transporters $\mathrm{SbtA}$ (a sodium-dependent $\mathrm{HCO}_{3}{ }^{-}$symporter; with a $\mathrm{K}_{0.5}$ for bicarbonate $<5 \mu \mathrm{M}$ and low flux of $\mathrm{HCO}_{3}{ }^{-}$uptake), which was shown recently to be allosterically regulated [57], and BicA (a sulfate permease or SulP-type sodium-dependent $\mathrm{HCO}_{3}$ - transporter $)$ that has a low affinity for $\mathrm{HCO}_{3}{ }^{-}\left(\mathrm{K}_{0.5}=70-150 \mu \mathrm{M}\right)$ and a high flux of $\mathrm{HCO}_{3}{ }^{-}$uptake [55,58]. Another cyanobacterial system comprises two thylakoid $\mathrm{CO}_{2}$ uptake systems based on $\mathrm{NAD}(\mathrm{P}) \mathrm{H}$ dehydrogenase type $1\left(\mathrm{NDH}-1_{3} / 4\right)$ that are also induced by carbon limitation [59-61].

Eukaryotic microalgal bicarbonate transport is more complex than that of cyanobacteria, since the eukaryotic cell contains organelles surrounded by membranes. In the green alga Chlamydomonas reinhardtii, two plasma membrane transporters, high-light activated protein, $\mathrm{HLA} 3$ and low $\mathrm{CO}_{2}$ inducible protein, LCI1, have been well studied; more recently, a new transporter, CIA8 (for Ci accumulation), was shown to be needed for optimal growth at low $\mathrm{CO}_{2}$ and for bicarbonate uptake and could be located within the thylakoid membrane [62]. Chloroplast membrane transporters include the LCIA (also known as NAR1.2), which is known to form a complex with the soluble protein LCIB [63]. Two proteins, CCP1 and CCP2, with similarity to mitochondrial carrier proteins are believed to be involved in bicarbonate uptake in the chloroplast. However, the mutants of these proteins do not show an abnormal carbon concentration phenotype; thus, their involvement in CCM is not yet clear [64].

In diatoms, bicarbonate uptake has been studied in the two model species Phaeodactylum tricornutum and Thalassiosira pseudonana. The inorganic flux of carbon in diatoms has been estimated to increase $\mathrm{CO}_{2}$ around Rubisco up to $60 \mu \mathrm{M}$, just above the half-saturation concentration [35]. A plasma membrane-bound bicarbonate transporter from P. tricornutum belongs to the solute carrier 4 family (SLC4) and seems to be closely related to a human type rather than those found in green algae [65]. Moreover, three out of seven SLC4 genes found in P. tricornutum are induced by low $\mathrm{CO}_{2}$ and are highly inhibited by the anion exchange inhibitor 4,4'-Diisothiocyanostilbene-2,2'-disulfonic acid (DIDS) [65]. SLC4 family proteins are also believed to occur in T. pseudonana as gene homologs to those in $P$. tricornutum have been found [66]; however, their function has not been studied yet.

\section{Diversity of Carbonic Anhydrases in Microalgae and Their Importance in the CCM}

Carbonic anhydrases are widely distributed in photosynthetic organisms [10] and play an important role in $\mathrm{HCO}_{3}{ }^{-} / \mathrm{CO}_{2}$ uptake and in the concentration of $\mathrm{CO}_{2}$ around Rubisco in microalgae. $\alpha$-CA was first discovered in erythrocytes and widely studied in mammals [67-70], but it is also present in higher plants, algae, and cyanobacteria, among other organisms within all the kingdoms of life. $\alpha$-CAs are often more active than other classes of CA [10] and are typically found as monomers; however, one type, in the fungus Aspergillus oryzae, is a dimer [71] and two $\alpha$-CAs in C. reinhardtii (CAH1 and CAH2) are tetramers [72]. In C. reinhardtii, 12 genes that encode CA isoforms, including three alpha, six beta, and three gamma or gamma-like CAs [73], have been reported and more recently, three more beta CAs have been described [74] (Figure 1). Another extracellular $\alpha-\mathrm{CA}, \mathrm{EcaA}$, from cyanobacteria is also found in the periplasmic space; however, it does not have a role in the CCM [75,76]. In the marine eustigmatophyte Nannochloropsis oceanica, the CAH1 located in the lumen of the epiplastid endoplasmic reticulum is also essential for the CCM [77]. Other $\alpha$-CAs having a possible role in CCMs are found in many other photosynthetic organisms, including haptophytes, rhodophytes, phaeophytes, and cryptomonads [10].

$\beta$-CA was discovered in chloroplasts from leaves [78]. They are present in most photosynthetic organisms, and in some non-photosynthetic microorganisms, but not in animals [74]. In contrast to the $\alpha$-CAs, $\beta$-CAs are more frequently found in different oligomeric states, and several trimeric 
and tetrameric structures have been reported [79-81]. This class of CA is the best studied in land plants, and the role of $\beta$-CA in the CCM of terrestrial $\mathrm{C} 4$ plants has been well established, where it is mainly expressed in the cytoplasm of mesophyll cells, thus providing the $\mathrm{HCO}_{3}{ }^{-}$required for phosphoenolpyruvate carboxylase $[18,82]$. $\beta$-CA is highly expressed in the green tissues of $C 3$ plants, suggesting a possible role in photosynthesis [83], and in Arabidopsis thaliana, two cytoplasmic $\beta$-CAs are essential for growth at low $\mathrm{CO}_{2}$ [84]. In cyanobacteria containing $\alpha$-carboxysomes, a $\beta$-CA (CsoSCA) is present in the carboxysome shell [85] (Figure 1); this CA was first proposed as a new sub-class, which was called $\varepsilon$ (epsilon), but later it was shown that the $\varepsilon$-CA is just a modified $\beta$-CA, and this denomination is no longer used $[86,87]$.

The $\gamma$-CA is a trimeric protein first described in Archaea [88], but it is also present in photosynthetic organisms [10]. In the cyanobacterium Synechococcus PCC7002, the protein CcmM, a component of the $\beta$-carboxysomes, is a $\gamma$-CA that shares $34 \%-36 \%$ identity with the active site of that from the anaerobic methane-producing species Methanosarcina thermophila from the Archaea domain with the amino acids involved in $\mathrm{Zn}^{2+}$ coordination perfectly conserved [75]. Although the Archaean type is able to replace $\mathrm{Zn}^{2+}$ by $\mathrm{Fe}^{2+}$ [89], this feature has not been observed in photosynthetic organisms. In contrast, in microalgae and plants, $\gamma$-CAs are located in mitochondria, and it is not clear whether they are involved in the CCM or not [18]. However, Wei et al. [90] reported that the RNAi-based down-regulation of a $\gamma$-CA in N. oceanica significantly decreased cell growth in cells grown at air $\mathrm{CO}_{2}$ and affected photosynthetic oxygen evolution; thus, this CA is likely to play a role in the CCM, although it is predicted as a mitochondrial protein. So far, the CA activity of other putative $\gamma$-CAs from eukaryotic algae has not been shown, and more work is needed to determine their physiological role and possible involvement in CCMs.

Three of the eight known CA classes were first discovered in diatoms [11,12,17,91]. In addition, the highly variable number, classes, and distribution of CAs in diatoms is unique compared to other organisms and might be related to their complex evolutionary origin $[92,93]$. The subcellular localization of several CAs present in diatom genomes has been predicted or experimentally demonstrated $[66,94,95]$ (Figure 1). In P. tricornutum, five $\alpha$-CAs are located in the four-layered chloroplast membrane, while in T. pseudonana, only one is present in the chloroplast stroma [95]. In addition, only two $\beta$-CAs have been found in the pyrenoid of P. tricornutum and none have been found in T. pseudonana. Two $\gamma$-CAs are also found in the mitochondria of P. tricornutum and three have been found in T. pseudonana; in the latter species, there is also a $\gamma$-CA in the cytoplasm. However, as in other algae, the activity and the role of the $\gamma$-CA in the diatom CCM has not been studied.

The $\delta$-CA and the $\zeta$-CA were both first discovered in the marine diatom T. weissflogii $[17,91]$. The $\delta$-CA has been observed in algae derived from secondary endosymbiosis and in prasinophytes [10]. Surprisingly, the $\delta-C A$ is a cambialistic CA, where $\mathrm{Zn}^{2+}$ can be replaced by $\mathrm{Co}^{2+}$ at the active site [21], and in the $\zeta-\mathrm{CA}, \mathrm{Zn}^{2+}$ can be replaced by $\mathrm{Cd}^{2+}[96]$. The CDCA ( $\left.\zeta-\mathrm{CA}\right)$ from T. weissflogii has a catalytic efficiency $\left(\mathrm{k}_{\text {cat }} / \mathrm{K}_{\mathrm{m}}\right)$ of $8.7 \times 10^{8} \mathrm{M}^{-1} \mathrm{~s}^{-1}$ when $\mathrm{Zn}^{2+}$ is bound and $1.4 \times 10^{8} \mathrm{M}^{-1} \mathrm{~s}^{-1}$ when $\mathrm{Cd}^{2+}$ is bound [23]. These values are comparable to other $\alpha$-CAs, such as the human CAII $\left(\mathrm{k}_{\mathrm{cat}} / \mathrm{K}_{\mathrm{m}}=1.5 \times 10^{8} \mathrm{M}^{-1} \mathrm{~s}^{-1}\right)$ [97]. The $\zeta$-CA occurs naturally in several diatom species, including those from the genus Thalassiosira [98].

$\theta$-CA is found in the lumen of the thylakoids in P. tricornutum [11]. It is likely that its role is to convert $\mathrm{HCO}_{3}{ }^{-}$into $\mathrm{CO}_{2}$ inside the thylakoid lumen [10]. In addition, when the mRNA for $\theta-\mathrm{CA}$ was silenced in P. tricornutum, the growth rate was lower than that of the wild type at air equilibrium and at high $\mathrm{CO}_{2}$ concentration, suggesting that this $\mathrm{CA}$ plays a fundamental role in photosynthesis and not just in the CCM [11]. The LCIB from C. reinhardtii was originally described as a $\beta$-CA [24] but subsequently classified as an ortholog of a $\theta$-CA with a Cys-Gly-His rich (CGHR) domain [99]. It is found around the pyrenoid and might be involved in the prevention of $\mathrm{CO}_{2}$ leakage from the pyrenoid to the chloroplast stroma [24,100]. BLAST (Basic Local Alignment Search Tool) analysis shows that the $\theta$-CA is also present in the diatoms T. pseudonana, T. oceanica, Fragilariopsis cylindrus, and Fistulifera solaris, suggesting that this CA could be widespread among diatoms (Figure 2) [1]. 

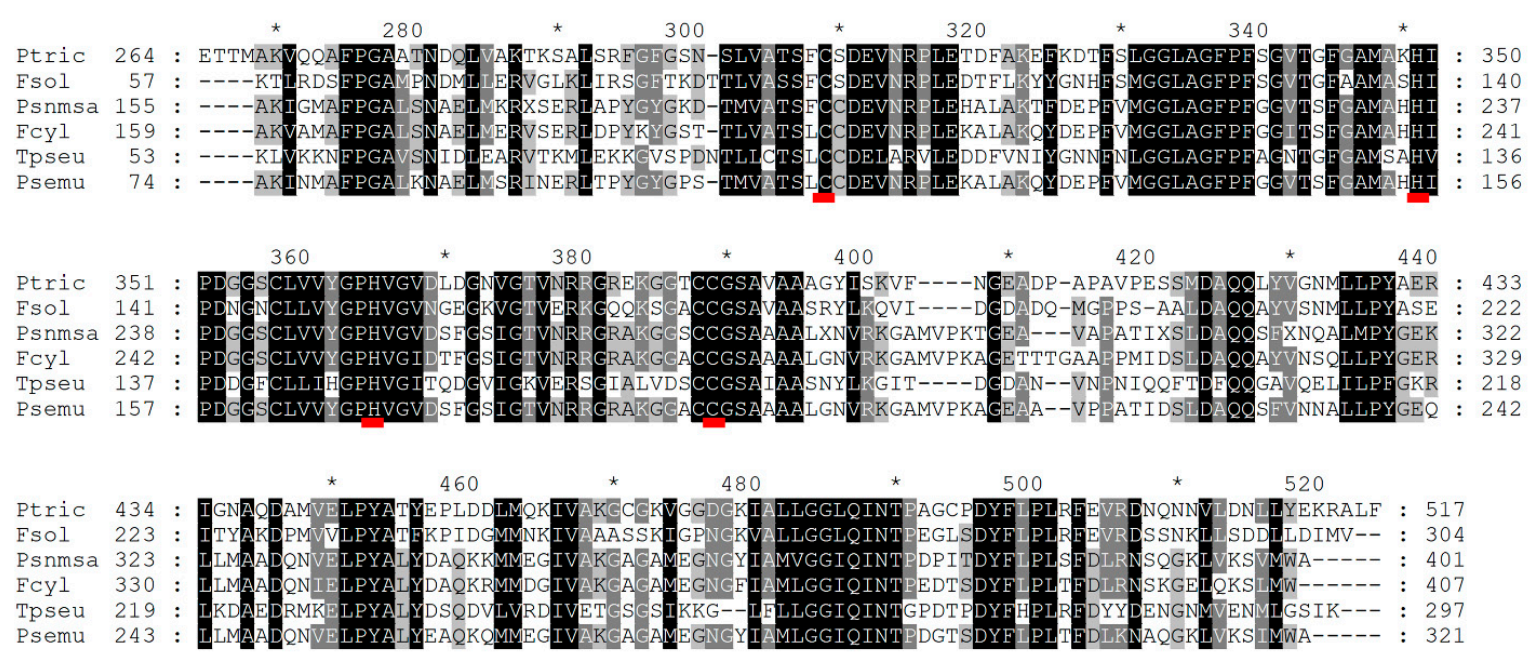

Figure 2. Alignment of the $\theta$-CA from different diatom species. Only partial sequences are shown. Black, dark gray, and light gray indicate $80 \%$ or above, $70 \%$, and $60 \%$ of amino acid identity, respectively. Species and protein IDs are the following: Ptric, Phaeodactylum tricornutum (protein ID: XP_002177507.1 - NCBI; 517 aa); Fsol, Fistulifera solaris (protein ID: GAX24004.1 - NCBI; 304 aa); Psnma, Pseudo-nitzchia multistriata (protein ID: VEU35824.1 - NCBI; 401); Fcyl, Fragilariopsis cylindrus (protein ID: OEU22620.1 - NCBI; 407 aa); Tpseu, Thalassiosira pseudonana (protein ID: XP_002297283.1 - NCBI; 297 aa); Psemu, Pseudo-nitzchia multiseries (protein ID: 239261 - JGI; 321 aa). The amino acids underlined in red are possibly involved in the active site, as shown by Kikutani et al. [11] Alignments were performed with ClustalW, using MEGAX software, and the figure was processed with GeneDoc.

Finally, the most recently discovered class, I-CA, was highly expressed in T. pseudonana grown at low $\mathrm{CO}_{2}[101,102]$. This class uses $\mathrm{Mn}^{2+}$ as a cofactor, while no activity has been observed in the presence of $\mathrm{Zn}^{2+}$ or other metals [12]. In addition, it has been shown that ı-CA plays a role in the diatom $\mathrm{CCM}$, as it dramatically increases the affinity for $\mathrm{CO}_{2}$ when overexpressed [12]. Moreover, it has been proposed to be located in the periphery of the chloroplast, presumably in the chloroplast endoplasmic reticulum (CER) boundary (Figure 1). Sequence comparison and phylogenetic analyses show that เ-CA is widely distributed in marine phytoplankton, including other diatom species, haptophytes, cryptomonads, and pelagophytes [1,12].

\section{Regulation of CA Expression}

In the green alga $C$. reinhardtii, the two periplasmic $\alpha$-CA, CAH1 and $\mathrm{CAH} 2$, show an opposite regulation upon environmental $\mathrm{CO}_{2}$ : $\mathrm{CAH} 1$ is more abundant under low $\mathrm{CO}_{2}$, while $\mathrm{CAH} 2$ is more abundant under high $\mathrm{CO}_{2}$ [72]. In N. oceanica, $\mathrm{CAH} 1$ was also more abundant in cells cultured at low $\mathrm{CO}_{2}$ [77]. Blanco-Rivero et al. (2012) showed that after $C$. reinhardtii cells are transfered to low $\mathrm{CO}_{2}$, the thylakoid luminal CAH3 becomes phosphorylated, more active, and is relocated from the photosystems II area where it is associated to its electron donor side toward the pyrenoi-a specialized compartment inside the chloroplast that is analogous to the carboxysome present in cyanobacteria, where Rubisco is packed together with carbonic anhydrases [103]. As has been observed for CAH3, it is likely that post-translational modifications triggered by low $\mathrm{CO}_{2}$ are also present in other $\alpha$-CAs. In contrast, the two closely related $\beta$-CAs, CAH7 and CAH8 (Figure 1), are not regulated by $\mathrm{CO}_{2}$ [104].

The transcriptional regulation of $C A$ expression has been studied in $C$. reinhardtii. The expression of the low $\mathrm{CO}_{2}$-inducible $\mathrm{CAH} 3$ appears to be tightly regulated by the master regulator of the $\mathrm{CO}_{2}$ response CCM1 (CIA5) [105]. Another gene, encoding for CAH1, is also a $\mathrm{CO}_{2}$-responsive gene regulated by the Myb transcription factor LCR1 [106]. However, no homolog proteins of CCM1 and LCR1 have been described in stramenopiles, alveolates, or haptophytes. In diatoms, it is believed that a transcriptional regulation of the response to $\mathrm{CO}_{2}$ might exist, which is mediated by the second 
messenger cAMP [107]. In fact, a bZIP transcription factor in P. tricornutum (ptbZIP11) is shown to bind specifically to a $\mathrm{CO}_{2}$-cAMP responsive element in the regulatory region of the $p t c a 1$ gene, encoding for the pyrenoidal $\beta$-CA [108].

The patterns of $\mathrm{CA}$ expression in response $\mathrm{CO}_{2}$ concentration and their role in CCMs differ among species. For example, in the coccolithophore Emiliania huxleyi, the transcript of a $\delta$-CA is highly expressed, but it is not affected by the presence of $\mathrm{CO}_{2}$, and its role in the CCM is unclear [109]. In the marine dinoflagellate Lingulodinium polyedrum, it is unclear whether the expression of an external $\delta$-CA is regulated by $\mathrm{CO}_{2}$ concentration; however, this enzyme is important in increasing $\mathrm{CO}_{2}$ availability at the cell surface [110]. In contrast, the $\delta$-CA from T. weissflogii and T. pseudonana (found in the periplasmic space) are highly up-regulated in cells grown at low $\mathrm{CO}_{2}[101,111]$. In addition, in $T$. pseudonana, McGinn and Morel (2008) showed that the expression of two isoforms of the $\delta$-CA (Tp1 and Tp2) is down-regulated at the level of protein and transcripts at low concentrations of $\mathrm{Zn}$ or Co. A similar pattern of regulation in response to low $\mathrm{CO}_{2}$ and $\mathrm{Zn}$ concentration was observed for the Cd-containing $\zeta$-CA (CDCA) [22].

Since many CAs participate actively in photosynthetic $\mathrm{CO}_{2}$ fixation, it is not surprising that their activity is coordinated with diel changes in light availability and the activity of the whole photosynthetic machinery. Many responses to light and dark are mediated by redox conditions within the cell. Two major redox systems exist, based on thioredoxin or glutaredoxin, that are ubiquitous and able to regulate several cellular processes through dithiol-disulfide exchanges with proteins. In P. tricornutum, the two pyrenoid-localized $\beta$-CAs (Figure 1), named PtCA1 and PtCA2, are regulated by thioredoxins [112,113], while in A. thaliana, the chloroplastic $\beta$-CA (ID: At3g01500) is regulated by glutaredoxins $[112,113]$. In addition, $\mathrm{PtCA} 1$ is also regulated by $\mathrm{CO}_{2}$ and light $[114,115]$, suggesting that in diatoms, $\mathrm{CO}_{2}$ uptake in the pyrenoid might be controlled by thioredoxins. Moreover, transcriptional regulation may also occur, since the mRNA expression of ptcal is down-regulated at high $\mathrm{CO}_{2}$ concentration at the promoter level $[115,116]$. The CAH8 from C. reinhardtii is homologous to the $\beta$-CA in $A$. thaliana and thus it might be redox regulated, but this needs to be investigated further. However, redox regulation of $\beta$-CA also occurs in non-photosynthetic organisms. For example, oxidation of the $\beta$-CA from the pathogen Mycobacterium tuberculosis can trigger the formation of a disulfide bond at the active site involving the cysteine residues that coordinate the catalytic metal ion, thereby leading to its inactivation [117]. In this case, oxidation can be triggered either by air and $\mathrm{H}_{2} \mathrm{O}_{2}$ but also by some oxidative compounds derived from the host.

\section{Other Roles of CAs in Microalgae}

Carbonic anhydrases are involved in other physiological and metabolic processes in cells, other than the $\mathrm{CO}_{2}$-related metabolism described above. In fact, the first function reported for a CA was on the transport and elimination of $\mathrm{CO}_{2}$ through blood in mammals [118,119]. CAs have been also shown to be essential in acid-base homeostasis in different organisms, including mammals, fish, and arthropods [120]. In plants, the mutation of genes encoding for $\beta$-CAs affects the $\mathrm{CO}_{2}$ and environmental-induced stomatal response in A. thaliana and Z. mays [121,122]. Other roles of CAs in plants include plastid lipid biosynthesis [123] and the regulation of carbon metabolism during root development [124].

Little is known about other roles of CAs in photosynthetic microalgae. A cia1 mutant $C$. reinhardii, which is known to have a high requirement for $\mathrm{CO}_{2}$ and carrying two mutations in the thylakoid luminal $\alpha$-CA CAH3, is much less effective at carrying out fatty acid (FA) desaturation in the thylakoid membrane. A role of this CA in the control of the composition of the photosynthetic membrane has been proposed [125]. In fact, highly unsaturated FAs are believed to be important for the normal function of photosystems I and II by affecting membrane fluidity [126]. Mackinder et al. (2017) showed that $\mathrm{CAH} 3$ also interacts with the proteins from the twin-arginine translocation (tat) pathway, TAT2 and TAT3, and so CAs may also be involved in the transport of proteins to the thylakoid lumen [127]. 
Chemotaxis towards $\mathrm{HCO}_{3}{ }^{-}$has been demonstrated in C. reinhardtii [128] and toward $\mathrm{CO}_{2}$ for five species of microalgae [129]. In this regard, the $\beta-\mathrm{CA}, \mathrm{CAH} 6$, is expressed in the flagella of $C$. reinhardtii, and thus, it might be involved in chemotactic movements triggered by environmental inorganic carbon concentrations [127].

A role of mitochondrial CAs in anaplerotic carbon incorporation into the tricarboxylic acid (TCA) cycle has been proposed, in which $\mathrm{HCO}_{3}{ }^{-}$is supplied to the cytosolic phosphoenolpyruvate carboxylase (PEPC) of C. reinhardtii [130]. In contrast, diatoms have no predicted cytosolic PEPC, but a mitochondrial PEPC (PEPC2) is predicted in T. pseudonana and P. tricornutum instead [131], suggesting that the same anaplerotic role of mitochondrial CAs is also likely to occur in diatoms. This is even more relevant as these reactions occur in the same compartment; however, this needs to be investigated further.

\section{Microalgal CAs and the Ecology of Aquatic Environments}

The discovery of CAs that are capable of replacing zinc by other metal ions is of significant relevance, as it reveals an adaptation to the availability of trace metals, and this might have contributed to the ecological success of many photosynthetic microalgae, especially diatoms. This has been extensively reviewed recently by Morel et al. (2020) [15], so we focus specifically on Mn, which is the cofactor of the newly discovered ı-CA [12].

In marine environments, particularly in coastal waters and estuaries, manganese is more abundant than zinc by up to $20-50$ times [132,133]. In addition, $\mathrm{Mn}^{2+}$ is a cofactor of several other enzymes, such as the Mn-superoxide dismutase (MnSOD) [134], and it is an important component of the photosystem II reaction center $[135,136]$. Indeed, in T. pseudonana, the MnSOD is located in the chloroplast and is the dominant SOD in the cell [134]. Then, it is possible that the total CA activity in T. pseudonana relies on $\mathrm{Mn}^{+2}$ as well as $\mathrm{Zn}^{2+}, \mathrm{Co}^{2+}$, and $\mathrm{Cd}^{2+}$. Sunda and Huntsman [132] showed that the range of free $\mathrm{Mn}^{2+}$ concentration in which there is a cellular regulation of $\mathrm{Mn}^{2+}$ is related to the $\mathrm{Mn}^{2+}$ concentration found in the natural habitats where diatoms live.

Response to $\mathrm{Mn}^{2+}$ availability at the genetic level has been studied in several organisms. In the bacterium Agrobacterium tumefaciens, 55 genes were differentially expressed in manganese-limited cells, and the cells showed a reduction in biofilm formation [137]. Furthermore, the Mn-sensing transcriptional regulator MtsR controls the expression of genes related to $\mathrm{Mn}^{2+}$ uptake as well as genes controlling Streptococcus pyrogenes virulence [138]. In cyanobacteria, a Mn-sensing signaling system, Hik27-Rre16, regulates $\mathrm{Mn}^{2+}$ homeostasis by controlling the expression of a $\mathrm{Mn}^{2+}$-specific $\mathrm{ABC}$ transporter in response to $\mathrm{Mn}^{2+}$ availability $[139,140]$. In C. reinhardtii grown at limited $\mathrm{Mn}^{2+}$ concentrations, there is a strong down-regulation of genes involved in photosystem II function and up-regulation of the MnSOD gene; cells also showed defective photosynthesis and a loss of MnSOD activity [141]. It is possible that $\mathrm{Mn}$ has an effect on the expression of $\mathrm{l}-\mathrm{CA}$, and this is currently under investigation in Gontero's group.

\section{Conclusions}

The first occurrence of CA (an $\alpha$-CA) in plants was confirmed in 1939. The discovery of $\beta$-CAs in plants in 1990 continued with the finding of multiple $\alpha$ - and $\beta$-CAs in C. reinhardtii and A. thaliana [18]. Subsequently, there has been a resurgence of interest in CAs from plants and algae over the past decade. Recent work on marine diatoms has uncovered further distinct classes of $C A$, some of which make use of metal cations other than zinc at the active site including I-CA, which is widespread among marine phytoplankton, bacteria, and archaea. CA's diversity, ubiquitous distribution, and multiple forms and location within an organism are testament to the fundamental importance of this enzyme to life on Earth. CA not only has consequences for global productivity but also for the biogeochemistry of trace metals in the ocean. The availability of bioinformatic tools to analyze the ever-growing number of sequenced genomes from algal species will help the global diversity and distribution of CAs to 
be investigated. Molecular approaches such as overexpression, gene silencing by CRISP/Cas9, and structural studies will shed light on the numerous metabolic roles of CAs in photosynthetic organisms.

Author Contributions: All authors participated in the conception of this review article. E.L.J. prepared the figures and the draft of this manuscript, supervised by S.C.M. and B.G. All authors participated in writing, reading and reviewing the final manuscript. All authors have read and agreed to the published version of the manuscript.

Funding: This research was supported by the Centre National de la Recherche Scientifique (CNRS), Aix-Marseille Université, Agence Nationale de la Recherche (Signaux-BioNRJ, ANR-15-CE05-0021-03). E.L.J. studentship was funded by Comision Nacional de Investigacion Cientifica y tecnologica (conicyt)—Programa de formacion humano avanzado Becas Chile 2015/2019.

Conflicts of Interest: The authors declare no conflict of interest.

\section{References}

1. Nonoyama, T.; Kazamia, E.; Nawaly, H.; Gao, X.; Tsuji, Y.; Matsuda, Y.; Bowler, C.; Tanaka, T.; Dorrell, R. Metabolic Innovations Underpinning the Origin and Diversification of the Diatom Chloroplast. Biomolecules 2019, 9, 322. [CrossRef] [PubMed]

2. Soo, R.M.; Hemp, J.; Parks, D.H.; Fischer, W.W.; Hugenholtz, P. On the origins of oxygenic photosynthesis and aerobic respiration in Cyanobacteria. Science 2017, 1440, 1436-1440. [CrossRef] [PubMed]

3. Yoon, H.S.; Hackett, J.D.; Ciniglia, C.; Pinto, G.; Bhattacharya, D. A molecular timeline for the origin of photosynthetic eukaryotes. Mol. Biol. Evol. 2004, 21, 809-818. [CrossRef] [PubMed]

4. Dorrell, R.G.; Bowler, C. Secondary Plastids of Stramenopiles. In Advances in Botanical Research, 1st ed.; Elsevier Ltd.: Amsterdam, The Netherlands, 2017. [CrossRef]

5. Keeling, P.J. The endosymbiotic origin, diversification and fate of plastids. Philos. Trans. R. Soc. B Biol. Sci. 2010, 365, 729-748. [CrossRef] [PubMed]

6. Bhola, V.; Swalaha, F.; Kumar, R.R.; Singh, M.; Bux, F. Overview of the potential of microalgae for $\mathrm{CO}_{2}$ sequestration. Int. J. Environ. Sci. Technol. 2014, 11, 2103-2118. [CrossRef]

7. Raven, J.A.; Giordano, M.; Beardall, J.; Maberly, S.C. Algal evolution in relation to atmospheric mechanisms and carbon oxidation cycles. Philos. Trans. R. Soc. 2012, 367, 493-507. [CrossRef]

8. Raven, A. Photosynthetic and non-Photosynthetic roles of carbonic anhydrase in algae and cyanobacteria. Phycologia 1995, 34, 93-101. [CrossRef]

9. Lionetto, M.G.; Caricato, R.; Giordano, M.E.; Schettino, T. The complex relationship between metals and carbonic anhydrase: New insights and perspectives. Int. J. Mol. Sci. 2016, 17, 127. [CrossRef]

10. DiMario, R.J.; Machingura, M.C.; Waldrop, G.L.; Moroney, J.V. The many types of carbonic anhydrases in photosynthetic organisms. Plant Sci. 2018, 268, 11-17. [CrossRef]

11. Kikutani, S.; Nakajima, K.; Nagasato, C.; Tsuji, Y.; Miyatake, A.; Matsuda, Y. Thylakoid luminal $\theta$-Carbonic anhydrase critical for growth and photosynthesis in the marine diatom Phaeodactylum tricornutum. Proc. Natl. Acad. Sci. USA 2016, 113, 9828-9833. [CrossRef]

12. Jensen, E.L.; Clement, R.; Kosta, A.; Maberly, S.C.; Gontero, B. A new widespread subclass of carbonic anhydrase in marine phytoplankton. ISME J. 2019, 13, 2094-2106. [CrossRef] [PubMed]

13. Nocentini, A.; Supuran, C.T. Carbonic anhydrases: An overview. In Carbonic Anhydrases; Elsevier Inc.: Amsterdam, The Netherlands, 2019. [CrossRef]

14. Supuran, C.T. Carbonic Anhydrases and Metabolism. Metabolites 2018, 8, 25. [CrossRef] [PubMed]

15. Morel, F.M.M.; Lam, P.J.; Saito, M.A. Trace Metal Substitution in Marine Phytoplankton. Annu. Rev. Earth Planet. Sci. 2020, 48, 1-27. [CrossRef]

16. Del Prete, S.; Vullo, D.; Fisher, G.M.; Andrews, K.T.; Poulsen, S.A.; Capasso, C.; Supuran, C.T. Discovery of a new family of carbonic anhydrases in the malaria pathogen Plasmodium falciparum-The $\eta$-Carbonic anhydrases. Bioorganic Med. Chem. Lett. 2014, 24, 4389-4396. [CrossRef] [PubMed]

17. Lane, T.W.; Saito, M.A.; George, G.N.; Pickering, I.J.; Prince, R.C.; Morel, F.M.M. A cadmium enzyme from a marine diatom. Nature 2005, 435, 42. [CrossRef]

18. DiMario, R.J.; Clayton, H.; Mukherjee, A.; Ludwig, M.; Moroney, J.V. Plant Carbonic Anhydrases: Structures, Locations, Evolution, and Physiological Roles. Mol. Plant. 2017, 10, 30-46. [CrossRef] 
19. Whittington, D.A.; Waheed, A.; Ulmasov, B.; Shah, G.N.; Grubb, J.H.; Sly, W.S.; Christianson, D.W. Crystal structure of the dimeric extracellular domain of human carbonic anhydrase XII, a bitopic membrane protein overexpressed in certain cancer tumor cells. Proc. Natl. Acad. Sci. USA 2002, 98, 9545-9550. [CrossRef]

20. Supuran, C.T.; Capasso, C. An overview of the bacterial carbonic anhydrases. Metabolites 2017, 7, 56. [CrossRef]

21. Yee, D.; Morel, F.M.M. In vivo substitution in carbonic of zinc by cobalt of a marine anhydrase diatom. Limnol. Oceanogr. 2011, 41, 573-577. [CrossRef]

22. McGinn, P.J.; Morel, F.M.M. Expression and regulation of carbonic anhydrases in the marine diatom Thalassiosira pseudonana and in natural phytoplankton assemblages from Great Bay, New Jersey. Physiol. Plant. 2008, 133, 78-91. [CrossRef]

23. Xu, Y.; Feng, L.; Jeffrey, P.D.; Shi, Y.; Morel, F.M.M.M. Structure and metal exchange in the cadmium carbonic anhydrase of marine diatoms. Nature 2008, 452, 56-61. [CrossRef] [PubMed]

24. Jin, S.; Sun, J.; Wunder, T.; Tang, D.; Cousins, A.B.; Sze, S.K.; Mueller-Cajar, O.; Gao, Y.-G. Structural insights into the LCIB protein family reveals a new group of $\beta$-Carbonic anhydrases. Proc. Natl. Acad. Sci. USA 2016, 113, 14716-14721. [CrossRef] [PubMed]

25. Kim, J.; Lee, K.; Lee, H.; Kim, M. The effect of seawater $\mathrm{CO}_{2}$ concentration on growth of a natural phytoplankton assemblage in a controlled mesocosm experiment. Limnol. Oceanogr. 2006, 51, 1629-1636. [CrossRef]

26. Gattuso, J.; Gao, K.; Lee, K.; Rost, B.; Schulz, K.G. Approaches and tools to manipulate the carbonate chemistry. In Guid. to Best Pract. Ocean Acidif. Res. Data Report; Riebesell, U., Fabry, V., Hansson, L., Gattuso, J., Eds.; Publications Office ofthe European Union: Luxembourg, 2010; pp. 41-52.

27. Gao, K.; Campbell, D.A. Photophysiological responses of marine diatoms to elevated $\mathrm{CO}_{2}$ and decreased pH: A review. Funct. Plant Biol. 2014, 41, 449-459. [CrossRef]

28. Badger, M.R.; Andrews, T.J.; Whitney, S.M.; Ludwig, M.; Yellowlees, D.C.; Leggat, W.; Price, G.D. The diversity and coevolution of Rubisco, plastids, pyrenoids, and chloroplast-Based $\mathrm{CO}_{2}$-Concentrating mechanisms in algae. Can. J. Bot. 1998, 76, 1052-1071. [CrossRef]

29. Young, J.N.; Heureux, A.M.C.; Sharwood, R.E.; Rickaby, R.E.M.; Morel, F.M.M.; Whitney, S.M. Large variation in the Rubisco kinetics of diatoms reveals diversity among their carbon-Concentrating mechanisms. J. Exp. Bot. 2016, 67, 3445-3456. [CrossRef]

30. Heureux, A.M.C.; Young, J.N.; Whitney, S.M.; Eason-hubbard, M.R.; Lee, R.B.Y.; Sharwood, R.E.; Rickaby, R.E.M. The role of Rubisco kinetics and pyrenoid morphology in shaping the CCM of haptophyte microalgae. J. Exp. Bot. 2017, 68, 3959-3969. [CrossRef]

31. Husic, D.W.; Husic, H.D.; Tolbert, N.E.; Black, C.C. The oxidative photosynthetic carbon cycle or $\mathrm{C}_{2}$ cycle. CRC Crit. Rev. Plant Sci. 1987, 5, 45-100. [CrossRef]

32. Maberly, S.C.; Gontero, B. Ecological imperatives for aquatic carbon dioxide-Concentrating mechanisms. J. Exp. Bot. 2017, 68, 3797-3814. [CrossRef]

33. Raven, J.A.; Ball, L.A.; Beardall, J.; Giordano, M.; Maberly, S.C. Algae lacking $\mathrm{CO}_{2}$ concentrating mechanisms. Can. J. Bot. 2011, 83, 879-890. [CrossRef]

34. Matsuda, Y.; Nakajima, K.; Tachibana, M. Recent progresses on the genetic basis of the regulation of $\mathrm{CO}_{2}$ acquisition systems in response to $\mathrm{CO}_{2}$ concentration. Photosynth. Res. 2011, 109, 191-203. [CrossRef] [PubMed]

35. Hopkinson, B.M.; Dupont, C.L.; Allen, A.E.; Morel, F.M.M. Efficiency of the $\mathrm{CO}_{2}$-Concentrating mechanism of diatoms. Proc. Natl. Acad. Sci. USA 2011, 108, 3830-3837. [CrossRef] [PubMed]

36. Giordano, M.; Beardall, J.; Raven, J.A. $\mathrm{CO}_{2}$ concentrating mechanisms in algae: Mechanisms, Environmental Modulation, and Evolution. Annu. Rev. Plant Biol. 2005, 56, 99-131. [CrossRef] [PubMed]

37. Moroney, J.V.; Somanchi, A. How Do Algae Concentrate $\mathrm{CO}_{2}$ to Increase the Efficiency of Photosynthetic Carbon Fixation? Plant Physiol. 1999, 119, 9-16. [CrossRef]

38. Moroney, J.V.; Ynalvez, R.A. Proposed carbon dioxide concentrating mechanism in Chlamydomonas reinhardtii. Eukaryot. Cell 2007, 6, 1251-1259. [CrossRef]

39. Badger, M.R.; Price, G.D. $\mathrm{CO}_{2}$ concentrating mechanisms in cyanobacteria: Molecular components, their diversity and evolution. J. Exp. Bot. 2003, 54, 609-622. [CrossRef]

40. Hopkinson, B.M.; Dupont, C.L.; Matsuda, Y. The physiology and genetics of $\mathrm{CO}_{2}$ concentrating mechanisms in model diatoms. Curr. Opin. Plant Biol. 2016, 31, 51-57. [CrossRef] 
41. Bowes, G.; Rao, S.K.; Estavillo, G.M.; Reiskind, J.B. C4 mechanisms in aquatic angiosperms: Comparisons with terrestrial C4 systems. Funct. Plant Biol. 2002, 29, 379-392. [CrossRef]

42. Zhang, Y.; Yin, L.; Jiang, H.-S.; Li, W.; Gontero, B.; Maberly, S.C. Biochemical and biophysical $\mathrm{CO}_{2}$ concentrating mechanisms in two species of freshwater macrophyte within the genus Ottelia (Hydrocharitaceae). Photosynth. Res. 2014, 121, 285-297. [CrossRef]

43. Shao, H.; Gontero, B.; Maberly, S.C.; Jiang, H.S.; Cao, Y.; Li, W.; Huang, W.M. Responses of Ottelia alismoides, an aquatic plant with three CCMs, to variable $\mathrm{CO}_{2}$ and light. J. Exp. Bot. 2017, 68, 3985-3995. [CrossRef]

44. Xu, J.; Fan, X.; Zhang, X.; Xu, D.; Mou, S.; Cao, S.; Zheng, Z.; Miao, J.; Ye, N. Evidence of Coexistence of C3 and C4 Photosynthetic Pathways in a Green-Tide-Forming Alga, Ulva prolifera. PLoS ONE 2012, 7, e37438. [CrossRef] [PubMed]

45. Roberts, K.; Granum, E.; Leegood, R.C.; Raven, J.A. C3 and C4 Pathways of Photosynthetic Carbon Assimilation in Marine Diatoms Are under Genetic, Not Environmental, Control. Plant Physiol. 2007, 145, 230-235. [CrossRef]

46. Tanaka, R.; Kikutani, S.; Mahardika, A.; Matsuda, Y. Localization of enzymes relating to C4 organic acid metabolisms in the marine diatom, Thalassiosira pseudonana. Photosynth. Res. 2014, 121, 251-263. [CrossRef] [PubMed]

47. Clement, R.; Jensen, E.; Prioretti, L.; Maberly, S.C.; Gontero, B. Diversity of $\mathrm{CO}_{2}$ concentrating mechanisms and responses to $\mathrm{CO}_{2}$ concentration in marine and freshwater diatoms. J. Exp. Bot. 2017, 68, 3925-3935. [CrossRef] [PubMed]

48. Ewe, D.; Tachibana, M.; Kikutani, S.; Gruber, A.; Río Bártulos, C.; Konert, G.; Kaplan, A.; Matsuda, Y.; Kroth, P.G. The intracellular distribution of inorganic carbon fixing enzymes does not support the presence of a C4 pathway in the diatom Phaeodactylum tricornutum. Photosynth. Res. 2018, 137, 263-280. [CrossRef] [PubMed]

49. Clement, R.; Dimnet, L.; Maberly, S.C.; Gontero, B. The nature of the $\mathrm{CO}_{2}$-Concentrating mechanisms in a marine diatom, Thalassiosira pseudonana. New Phytol. 2016, 209, 1417-1427. [CrossRef] [PubMed]

50. Haimovich-dayan, M.; Garfinkel, N.; Ewe, D.; Marcus, Y.; Gruber, A.; Wagner, H.; Kroth, P.G.; Kaplan, A. The role of C4 metabolism in the marine diatom Phaeodactylum tricornutum. New Phytol. 2013, 197, 177-185. [CrossRef] [PubMed]

51. Spalding, M.H. Microalgal carbon-Dioxide-Concentrating mechanisms: Chlamydomonas inorganic carbon transporters. J. Exp. Bot. 2007, 59, 1463-1473. [CrossRef]

52. Price, G.D. Inorganic carbon transporters of the cyanobacterial $\mathrm{CO}_{2}$ concentrating mechanism. Photosynth. Res. 2011, 109, 47-57. [CrossRef]

53. Klanchui, A.; Cheevadhanarak, S.; Prommeenate, P.; Meechai, A. Exploring Components of the $\mathrm{CO}_{2}$-Concentrating Mechanism in Alkaliphilic Cyanobacteria Through Genome-Based Analysis. Comput. Struct. Biotechnol. J. 2017, 15, 340-350. [CrossRef] [PubMed]

54. Poschenrieder, C.; Fern, A.; Ter, J.; Barcel, J. Transport and Use of Bicarbonate in Plants: Current Knowledge and Challenges Ahead. Int. J. Mol. Sci. 2018, 19, 1352. [CrossRef] [PubMed]

55. Omata, T.; Price, G.D.; Badger, M.R.; Okamura, M.; Gohta, S.; Ogawa, T. Identification of an ATP-Binding cassette transporter involved in bicarbonate uptake in the cyanobacterium Synechococcus sp. Strain PCC 7942. Proc. Natl. Acad. Sci. USA 1999, 96, 13571-13576. [CrossRef] [PubMed]

56. Mcginn, P.J.; Price, G.D.; Maleszka, R.; Badger, M.R. Inorganic Carbon Limitation and Light Control the Expression of Transcripts Related to the $\mathrm{CO}_{2}$-Concentrating Mechanism in the Cyanobacterium Synechocystis sp. Strain PCC6803 1. Plant Physiol. 2003, 132, 218-229. [CrossRef] [PubMed]

57. Kaczmarski, J.A.; Hong, N.; Mukherjee, B.; Wey, L.T.; Rourke, L.; Fo, B.; Peat, T.S.; Price, G.D.; Jackson, C.J. Structural Basis for the Allosteric Regulation of the SbtA Bicarbonate Transporter by the PII-Like Protein, SbtB, from Cyanobium sp. PCC7001. Biochemistry 2019, 58, 5030-5039. [CrossRef]

58. Price, G.D.; Woodger, F.J.; Badger, M.R.; Howitt, S.M.; Tucker, L. Identification of a SulP-Type bicarbonate transporter in marine cyanobacteria. Proc. Natl. Acad. Sci. USA 2004, 101, 18228-18332. [CrossRef]

59. Badger, M.R.; Price, G.D.; Long, B.M.; Woodger, F.J. The environmental plasticity and ecological genomics of the cyanobacterial $\mathrm{CO}_{2}$ concentrating mechanism. J. Exp. Bot. 2006, 57, 249-265. [CrossRef]

60. Shibata, M.; Ohkawa, H.; Kaneko, T.; Fukuzawa, H.; Tabata, S.; Kaplan, A.; Ogawa, T. Distinct constitutive and low- $\mathrm{CO}_{2}$-induced $\mathrm{CO}_{2}$ uptake systems in cyanobacteria: Genes involved and their phylogenetic relationship with homologous genes in other organisms. Proc. Natl. Acad. Sci. USA 2001, 98, 2-7. [CrossRef] 
61. Sandrini, G.; Tann, R.P.; Schuurmans, J.M.; Van Beusekom, S.A.M.; Matthijs, H.C.P.; Huisman, J. Diel Variation in Gene Expression of the $\mathrm{CO}_{2}$-Concentrating Mechanism during a Harmful Cyanobacterial Bloom. Front. Microbiol. 2016, 7, 1-16. [CrossRef]

62. Machingura, M.C.; Bajsa-hirschel, J.; Laborde, S.M.; Schwartzenburg, J.B.; Mukherjee, B.; Mukherjee, A.; Pollock, S.V.; Förster, B.; Price, G.D.; Moroney, J.V. Identification and characterization of a solute carrier, CIA8, involved in inorganic carbon acclimation in Chlamydomonas reinhardtii. J. Exp. Bot. 2017, 68, 3879-3890. [CrossRef]

63. Wang, Y.; Spalding, M.H. Acclimation to very low $\mathrm{CO}_{2}$ : Contribution of limiting $\mathrm{CO}_{2}$ inducible proteins, LCIB and LCIA, to onorganic carbon uptake in Chlamydomonas reinhardtii. Plant Physiol. 2014, 166, 2040-2050. [CrossRef]

64. Pollock, S.V.; Prout, D.L.; Godfrey, A.C.; Lemaire, S.D.; Moroney, J.V. The Chlamydomonas reinhardtii proteins Ccp1 and Ccp2 are required for long-term growth, but are not necessary for efficient photosynthesis, in a low- $\mathrm{CO}_{2}$ environment. Plant Mol. Biol. 2004, 56, 125-132. [CrossRef] [PubMed]

65. Nakajima, K.; Tanaka, A.; Matsuda, Y. SLC4 family transporters in a marine diatom directly pump bicarbonate from seawater. Proc. Natl. Acad. Sci. USA 2013, 110, 1767-1772. [CrossRef] [PubMed]

66. Matsuda, Y.; Hopkinson, B.M.; Nakajima, K.; Dupont, C.L.; Tsuji, Y. Mechanisms of carbon dioxide acquisition and $\mathrm{CO}_{2}$ sensing in marine diatoms: A gateway to carbon metabolism. Philos. Trans. R. Soc. B Biol. Sci. 2017, 372, 20160403. [CrossRef] [PubMed]

67. Meldrum, N.U.; Roughton, F.J.W. The state of carbon dioxide in blood. J. Physiol. 1933, 80, 143-170. [CrossRef]

68. Chegwidden, W.R.; Carter, N.D. Introduction to the carbonic anhydrases. In The Carbonic Anhydrases; Chegwidden, W.R., Carter, N.D., Edwards, Y.H., Eds.; Birkhäuser: Basel, Switzerland, 2000; pp. 13-28. [CrossRef]

69. Forster, R.E. Remarks on the discovery of carbonic anhydrase. In The Carbonic Anhydrases; Chegwidden, W.R., Carter, N.D., Edwards, Y.H., Eds.; Birkhäuser: Basel, Switzerland, 2000; pp. 1-11. [CrossRef]

70. Lomelino, C.L.; Andring, J.T.; McKenna, R. Crystallography and Its Impact on Carbonic Anhydrase Research. Int. J. Med. Chem. 2018, 2018, 1-21. [CrossRef]

71. Cuesta-Seijo, J.A.; Borchert, M.S.; Navarro-Poulsen, J.C.; Schnorr, K.M.; Mortensen, S.B.; Lo Leggio, L. Structure of a dimeric fungal $\alpha$-Type carbonic anhydrase. FEBS Lett. 2011, 585, 1042-1048. [CrossRef]

72. Ishida, S.; Muto, S.; Miyachi, S. Structural analysis of periplasmic carbonic anhydrase 1 of Chlamydomonas reinhardtii. Eur. J. Biochem. 1993, 214, 9-16. [CrossRef]

73. Moroney, J.V.; Ma, Y.; Frey, W.D. The carbonic anhydrase isoforms of Chlamydomonas reinhardtii: Intracellular location, expression, and physiological roles. Photosynth. Res. 2011, 109, 133-149. [CrossRef]

74. Aspatwar, A.; Haapanen, S.; Parkkila, S. An update on the metabolic roles of carbonic anhydrases in the model alga Chlamydomonas reinhardtii. Metabolites 2018, 8, 22. [CrossRef]

75. So, A.K.-C.; Espie, G.S. Cyanobacterial carbonic anhydrases. Can. J. Bot. 2005, 83, 721-734. [CrossRef]

76. Kupriyanova, E.V.; Sinetova, M.A.; Bedbenov, V.S.; Pronina, N.A.; Los, D.A. Putative extracellular $\alpha$-Class carbonic anhydrase, EcaA, of Synechococcus elongatus PCC 7942 is an active enzyme: A sequel to an old story. Metabolites 2018, 164, 576-586. [CrossRef] [PubMed]

77. Gee, C.W.; Niyogi, K.K. The carbonic anhydrase CAH1 is an essential component of the carbon-Concentrating mechanism in Nannochloropsis oceanica. Proc. Natl. Acad. Sci. USA 2017, 114, 4537-4542. [CrossRef]

78. Neish, A.C. Studies on Chloroplasts: Factors Affecting Their Flocculation and the Calculation of the Chloroplast Content of Leaf Tissue From Chemical Analysis. Biochem. J. 1938, 33, 293-299. [CrossRef] [PubMed]

79. Kimber, M.S.; Pai, E.F. The active site architecture of Pisum sativum $\beta$-Carbonic anhydrase is a mirror image of that of $\alpha$-Carbonic anhydrases. EMBO J. 2000, 19, 1407-1418. [CrossRef] [PubMed]

80. Cronk, J.D.; Endrizzi, J.A.; Cronk, M.R.; Neill, J.W.O. Crystal structure of E. coli $\beta$-Carbonic anhydrase, an enzyme with an unusual pH-Dependent activity. Protein Sci. 2001, 10, 911-922. [CrossRef] [PubMed]

81. Covarrubias, A.S.; Bergfors, T.; Jones, T.A.; Högbom, M. Structural mechanics of the pH-Dependent activity of $\beta$-Carbonic anhydrase from Mycobacterium tuberculosis. J. Biol. Chem. 2006, 281, 4993-4999. [CrossRef] [PubMed]

82. Hatch, M.D.; Burnell, J.N. Carbonic Anhydrase Activity in Leaves and Its Role in the First Step of C4 Photosynthesis. Plant Physiol. 1990, 93, 825-828. [CrossRef] 
83. Fabre, N.; Reiter, I.M.; Becuwe-linka, N.; Genty, B.; Rumeau, D. Characterization and expression analysis of genes encoding $\alpha$ and $\beta$ carbonic anhydrases in Arabidopsis. Plant Cell Environ. 2007, 30, 617-629. [CrossRef]

84. DiMario, R.J.; Quebedeaux, J.C.; Longstreth, D.J.; Dassanayake, M.; Hartman, M.M.; Moroney, J.V. The Cytoplasmic Carbonic Anhydrases $\beta$ CA2 and $\beta$ CA4 Are Required for Optimal Plant Growth at Low $\mathrm{CO}_{2}$. Plant Physiol. 2016, 171, 280-293. [CrossRef]

85. Kerfeld, C.A.; Melnicki, M.R. Assembly, function and evolution of cyanobacterial carboxysomes. Curr. Opin. Plant Biol. 2016, 31, 66-75. [CrossRef]

86. So, A.K.-C.; Espie, G.S.; Williams, E.B.; Shively, J.M.; Heinhorst, S.; Cannon, G.C. A novel evolutionary lineage of carbonic anhydrase (epsilon class) is a component of the carboxysome shell. J. Bacteriol. 2004, 186, 623-630. [CrossRef] [PubMed]

87. Sawaya, M.R.; Cannon, G.C.; Heinhorst, S.; Tanaka, S.; Williams, E.B.; Yeates, T.O.; Kerfeld, C.A. The structure of $\beta$-Carbonic anhydrase from the carboxysomal shell reveals a distinct subclass with one active site for the price of two. J. Biol. Chem. 2006, 281, 7546-7555. [CrossRef] [PubMed]

88. Alber, B.E.; Ferry, J.G. A carbonic anhydrase from the archaeon Methanosarcina thermophila. Proc. Natl. Acad. Sci. USA 2006, 91, 6909-6913. [CrossRef] [PubMed]

89. MacAuley, S.R.; Zimmerman, S.A.; Apolinario, E.E.; Evilia, C.; Hou, Y.M.; Ferry, J.G.; Sowers, K.R. The archetype $\gamma$-Class carbonic anhydrase (cam) contains iron when synthesized in vivo. Biochemistry 2009, 48, 817-819. [CrossRef] [PubMed]

90. Wei, L.; Xin, Y.; Wang, Q.; Yang, J.; Hu, H.; Xu, J. RNAi-Based targeted gene knockdown in the model oleaginous microalgae Nannochloropsis oceanica. Plant J. 2017, 89, 1236-1250. [CrossRef] [PubMed]

91. Roberts, S.B.; Lane, T.W.; Morel, F.M.M. Carbonic anhydrase in the marine diatom Thalassiosira weissflogii (Bacillariophyceae). J. Phycol. 1997, 33, 845-850. [CrossRef]

92. Armbrust, E.V.; Berges, J.A.; Bowler, C.; Green, B.R.; Martinez, D.; Putnam, N.H.; Zhou, S.; Allen, A.E.; Apt, K.E.; Bechner, M.; et al. The genome of the diatom Thalassiosira pseudonana: Ecology, evolution, and metabolism. Science 2004, 306, 79-86. [CrossRef]

93. Bowler, C.; Allen, A.E.; Badger, J.H.; Grimwood, J.; Jabbari, K.; Kuo, A.; Maheswari, U.; Martens, C.; Maumus, F.; Otillar, R.P.; et al. The Phaeodactylum genome reveals the evolutionary history of diatom genomes. Nature 2008, 456, 239-244. [CrossRef]

94. Samukawa, M.; Shen, C.; Hopkinson, B.M.; Matsuda, Y. Localization of putative carbonic anhydrases in the marine diatom, Thalassiosira pseudonana. Photosynth. Res. 2014, 121, 235-249. [CrossRef]

95. Tachibana, M.; Allen, A.E.; Kikutani, S.; Endo, Y.; Bowler, C.; Matsuda, Y. Localization of putative carbonic anhydrases in two marine diatoms, Phaeodactylum tricornutum and Thalassiosira pseudonana. Photosynth. Res. 2011, 109, 205-221. [CrossRef]

96. Alterio, V.; Langella, E.; De Simone, G.; Monti, S.M. Cadmium-Containing carbonic anhydrase CDCA1 in marine diatom Thalassiosira weissflogii. Mar. Drugs. 2015, 13, 1688-1697. [CrossRef] [PubMed]

97. Christianson, D.W.; Cox, J.D. Catalysis by metal-Activated hydroxide in zinc and manganese metalloenzymes. Annu. Rev. Biochem. 1999, 68, 33-57. [CrossRef] [PubMed]

98. Park, H.; Song, B.; Morel, F.M.M. Diversity of the cadmium-Containing carbonic anhydrase in marine diatoms and natural waters. Environ. Microbiol. 2007, 9, 403-413. [CrossRef] [PubMed]

99. Tsuji, Y.; Nakajima, K.; Matsuda, Y. Molecular aspects of the biophysical $\mathrm{CO}_{2}$-Concentrating mechanism and its regulation in marine diatoms. J. Exp. Bot. 2017, 68, 3763-3772. [CrossRef] [PubMed]

100. Yamano, T.; Tsujikawa, T.; Hatano, K.; Ozawa, S.I.; Takahashi, Y.; Fukuzawa, H. Light and low-CO ${ }_{2}$-Dependent LCIBLCIC complex localization in the chloroplast supports the carbon-Concentrating mechanism in Chlamydomonas reinhardtii. Plant Cell Physiol. 2010, 51, 1453-1468. [CrossRef]

101. Clement, R.; Lignon, S.; Mansuelle, P.; Jensen, E.; Pophillat, M.; Lebrun, R.; Denis, Y.; Puppo, C.; Maberly, S.C.; Gontero, B. Responses of the marine diatom Thalassiosira pseudonana to changes in $\mathrm{CO}_{2}$ concentration: A proteomic approach. Sci. Rep. 2017, 7, 42333. [CrossRef] [PubMed]

102. Valenzuela, J.J.; López García De Lomana, A.; Lee, A.; Armbrust, E.V.; Orellana, M.V.M.V.; Baliga, N.S. Ocean acidification conditions increase resilience of marine diatoms. Nat. Commun. 2018, 9, 2328. [CrossRef]

103. Blanco-Rivero, A.; Shutova, T.; Román, M.J.; Villarejo, A.; Martinez, F. Phosphorylation controls the localization and activation of the lumenal carbonic anhydrase in Chlamydomonas reinhardtii. PLoS ONE 2012, 7, e49063. [CrossRef] 
104. Ynalvez, R.A.; Xiao, Y.; Ayana, S.; Cunnusamy, K.; Moroney, J. Identification and characterization of two closely related beta-carbonic anhydrase from Chlamydomonas reinhardtii. Physiol. Plant. 2008, 133, 15-26. [CrossRef]

105. Miura, K.; Yamano, T.; Yoshioka, S.; Kohinata, T.; Inoue, Y. Expression Profiling-Based Identification of $\mathrm{CO}_{2}$-Responsive Genes Regulated by CCM1 Controlling a Carbon-Concentrating Mechanism in Chlamydomonas reinhardtii. Plant Physiol. 2004, 135, 1595-1607. [CrossRef]

106. Yoshioka, S.; Taniguchi, F.; Miura, K.; Inoue, T.; Yamano, T.; Fukuzawa, H. The Novel Myb Transcription Factor LCR1 Regulates the $\mathrm{CO}_{2}$-Responsive Gene Cah1, Encoding a Periplasmic Carbonic Anhydrase in Chlamydomonas reinhardtii. Plant Cell 2004, 16, 1466-1477. [CrossRef] [PubMed]

107. Young, J.N.; Morel, F.M.M. Biological oceanography: The $\mathrm{CO}_{2}$ switch in diatoms. Nat. Clim. Chang. 2015, 5, 1-2. [CrossRef]

108. Ohno, N.; Inoue, T.; Yamashiki, R.; Nakajima, K.; Kitahara, Y.; Ishibashi, M.; Matsuda, Y. $\mathrm{CO}_{2}$-cAMP-Responsive cis-Elements Targeted by a Transcription Factor with CREB/ATF-Like Basic Zipper Domain in the Marine Diatom. Plant Physiol. 2012, 158, 499-513. [CrossRef]

109. Soto, A.R.; Zheng, H.; Shoemaker, D.; Rodriguez, J.; Read, B.A.; Wahlund, T.M. Identification and preliminary characterization of two cDNAs encoding unique carbonic anhydrases from the marine alga Emiliania huxleyi. Appl. Environ. Microbiol. 2006, 72, 5500-5511. [CrossRef] [PubMed]

110. Lapointe, M.; MacKenzie, T.D.B.; Morse, D. An External $\delta$-Carbonic Anhydrase in a Free-Living Marine Dinoflagellate May Circumvent Diffusion-Limited Carbon Acquisition. Plant Physiol. 2008, 147, 1427-1436. [CrossRef]

111. Lane, T.W.; Morel, F.M.M. Regulation of Carbonic Anhydrase Expression by Zinc, Cobalt, and Carbon Dioxide in the Marine Diatom Thalassiosira weissflogii. Plant Physiol. 2000, 123, 345-352. [CrossRef]

112. Kikutani, S.; Tanaka, R.; Yamazaki, Y.; Hara, S.; Hisabori, T.; Kroth, P.G.; Matsuda, Y.; Yamazaki, Y.; Hara, S.; Kroth, P.G.; et al. Redox regulation of carbonic anhydrases via thioredoxin in chloroplast of the marine diatom Phaeodactylum tricornutum. J. Biol. Chem. 2012, 287, 20689-20700. [CrossRef]

113. Rouhier, N.; Villarejo, A.; Srivastava, M.; Gelhaye, E.; Keech, O.; Droux, M.; Finkemeier, I.; Samuelsson, G.; Dietz, K.J.; Jacquot, J.-P.; et al. Identification of Plant Glutaredoxin Targets. Antioxid. Redox Signal. 2005, 7, 919-929. [CrossRef]

114. Harada, H.; Matsuda, Y. Identification and characterization of a new carbonic anhydrase in the marine diatom Phaeodactylum tricornutum. Can. J. Bot. 2005, 916, 909-916. [CrossRef]

115. Harada, H.; Nakatsuma, D.; Ishida, M.; Matsuda, Y.; Harada, H.; Nakatsuma, D.; Ishida, M.; Matsuda, Y. Regulation of the Expression of Intracellular $\beta$-Carbonic Anhydrase in Response to $\mathrm{CO}_{2}$ and Light in the Marine Diatom Phaeodactylum tricornutum. Plant Physiol. 2017, 139, 1041-1050. [CrossRef]

116. Li, Y.; Zhuang, S.; Wu, Y.; Ren, H.; Chen, F.; Lin, X.; Wang, K.; Beardall, J.; Gao, K. Ocean Acidification modulates expression of genes and physiological performance of a marine diatom. PLoS ONE 2017, 12, 1-13. [CrossRef] [PubMed]

117. Nienaber, L.; Cave-freeman, E.; Cross, M.; Mason, L.; Bailey, U.; Amani, P.; Davis, R.A.; Taylor, P.; Hofmann, A. Chemical probing suggests redox-Regulation of the carbonic anhydrase activity of mycobacterial Rv1284. FEBS J. 2015, 282, 2708-2721. [CrossRef] [PubMed]

118. Geers, C.; Gros, G. Carbon Dioxide Transport and Carbonic Anhydrase in Blood and Muscle. Physiol. Rev. 2000, 80, 681-707. [CrossRef] [PubMed]

119. Fegler, J. Function of Carbonic Anhydrase in Blood. Nature 1944, 153, 137-138. [CrossRef]

120. Henry, R.P. The Role of Carbonic Anhydrase in Blood Ion and Acid-Base regulation. Amer. Zool. 1984, 251, 241-251. [CrossRef]

121. Hu, H.; Rappel, W.; Occhipinti, R.; Ries, A.; Böhmer, M.; You, L.; Xiao, C.; Engineer, C.B.; Boron, W.F.; Schroeder, J.I. Distinct Cellular Locations of Carbonic Anhydrases Mediate Carbon Dioxide Control of Stomatal Movements. Plant Physiol. 2015, 169, 1168-1178. [CrossRef]

122. Kolbe, A.R.; Brutnell, T.P.; Cousins, A.B.; Studer, A.J. Carbonic Anhydrase Mutants in Zea mays Have Altered Stomatal Responses to Environmental Signals. Plant Physiol. 2018, 177, 980-989. [CrossRef]

123. Hoang, C.V.; Chapman, K.D. Biochemical and Molecular Inhibition of Plastidial Carbonic Anhydrase Reduces the Incorporation of Acetate into Lipids in Cotton Embryos and Tobacco Cell Suspensions and Leaves. Plant Physiol. 2002, 128, 1417-1427. [CrossRef] 
124. Kavroulakis, N.; Flemetakis, E.; Aivalakis, G.; Katinakis, P. Carbon Metabolism in Developing Soybean Root Nodules: The Role of Carbonic Anhydrase. Mol. Plant Microbe Interact. 2000, 13, 14-22. [CrossRef]

125. Sinetova, M.A.; Kupriyanova, E.V.; Markelova, A.G.; Allakhverdiev, S.I.; Pronina, N.A. Identification and functional role of the carbonic anhydrase Cah3 in thylakoid membranes of pyrenoid of Chlamydomonas reinhardtii. Biochim. Biophys. Acta Bioenerg. 2012, 1817, 1248-1255. [CrossRef]

126. Sato, N.; Sonoike, K.; Tsuzuki, M.; Kawaguchi, A. Photosynthetic characteristics of a mutant of Chlamydomonas reinhardtii impaired in fatty acid desaturation in chloroplasts. Biochim. Biophys. Acta Bioenerg. 1996, 1274, 112-118. [CrossRef]

127. Mackinder, L.C.M.; Chen, C.; Leib, R.D.; Patena, W.; Blum, S.R.; Rodman, M.; Ramundo, S.; Adams, C.M.; Jonikas, M.C. A Spatial Interactome Reveals the Anatomy of the Algal $\mathrm{CO}_{2}$ Concentrating Mechanism. Cell 2017, 171, 1-28. [CrossRef]

128. Choi, H., II; Hwan, Y.; Kwak, S. Quantitative analysis of the chemotaxis of a green alga, Chlamydomonas reinhardtii, to bicarbonate using diffusion-Based microfluidic device. Biomicrofluidics 2016, 10, 1-15. [CrossRef]

129. Clegg, M.R.; Maberly, S.C.; Jones, R.I. Chemosensory behavioural response of freshwater phytoplanktonic flagellates. Plant Cell Environ. 2004, 27, 123-135. [CrossRef]

130. Giordano, M.; Norici, A.; Forssen, M.; Eriksson, M.; Raven, J.A.; Marche, P.; Bianche, V.B. An Anaplerotic Role for Mitochondrial Carbonic Anhydrase in Chlamydomonas reinhardtii. Plant Physiol. 2003, 132, 2126-2134. [CrossRef] [PubMed]

131. Kroth, P.G.; Chiovitti, A.; Gruber, A.; Martin-Jezequel, V.; Mock, T.; Parker, M.S.; Stanley, M.S.; Kaplan, A.; Caron, L.; Weber, T.; et al. A model for carbohydrate metabolism in the diatom Phaeodactylum tricornutum deduced from comparative whole genome analysis. PLOS ONE 2008, 3, e1426. [CrossRef]

132. Sunda, W.G.; Huntsman, S.A. Relationships among growth rate, cellular manganese concentrations and manganese transport kinetics in estuarine and oceanic species of the diatom Thalassiosira. J. Phycol. 1986, 22, 259-270. [CrossRef]

133. Sunda, W.G.; Huntsman, S.A. Cobalt and zinc interreplacement in marine phytoplankton: Biological and geochemical implications. Limnol. Oceanogr. 1995, 40, 1404-1417. [CrossRef]

134. Wolfe-Simon, F.; Starovoytov, V.; Reinfelder, J.R.; Schofield, O.; Falkowski, P.G. Localization and role of manganese superoxide dismutase in a marine diatom. Plant Physiol. 2006, 142, 1701-1709. [CrossRef]

135. Bondarava, N.; Un, S.; Krieger-Liszkay, A. Manganese binding to the $23 \mathrm{kDa}$ extrinsic protein of Photosystem II. Biochim. Biophys. Acta Bioenerg. 2007, 1767, 583-588. [CrossRef]

136. Sunda, W.G.; Huntsman, S.A. Interactive effects of external manganese, the toxic metals copper and zinc, and light in controlling cellular manganese and growth in a coastal diatom. Limnol. Oceanogr. 1998, 43, 1467-1475. [CrossRef]

137. Heindl, J.E.; Hibbing, M.E.; Xu, J.; Natarajan, R.; Buechlein, A.M.; Fuqua, C. Discrete Responses to Limitation for Iron and Manganese in Agrobacterium tumefaciens: Influence on Attachment and Biofilm Formation. J. Bacteriol. 2016, 198, 816-829. [CrossRef]

138. Do, H.; Makthal, N.; Chandrangsu, P.; Olsen, R.J.; Helmann, J.D.; Musser, J.M.; Kumaraswami, M. Metal sensing and regulation of adaptive responses to manganese limitation by MtsR is critical for group A streptococcus virulence. Nucleic Acids Res. 2019, 1, 1-18. [CrossRef]

139. Los, D.A.; Zorina, A.; Sinetova, M.; Kryazhov, S.; Mironov, K.; Zinchenko, V.V. Stress sensors and signal transducers in cyanobacteria. Sensors 2010, 10, 2386-2415. [CrossRef] [PubMed]

140. Ogawa, T.; Bao, D.H.; Katoh, H.; Shibata, M.; Pakrasi, H.B.; Bhattacharyya-Pakrasi, M. A two-component signal transduction pathway regulates manganese homeostasis in Synechocystis 6803, a photosynthetic organism. J. Biol. Chem. 2002, 277, 28981-28986. [CrossRef] [PubMed]

141. Allen, M.D.; Kropat, J.; Tottey, S.; Del Campo, J.A.; Merchant, S.S. Manganese Deficiency in Chlamydomonas Results in Loss of Photosystem II and MnSOD Function, Sensitivity to Peroxides, and Secondary Phosphorus and Iron Deficiency. Plant Physiol. 2006, 143, 263-277. [CrossRef]

(C) 2020 by the authors. Licensee MDPI, Basel, Switzerland. This article is an open access article distributed under the terms and conditions of the Creative Commons Attribution (CC BY) license (http://creativecommons.org/licenses/by/4.0/). 